\title{
Fragmente sloer in ons ore: die reaktivering van ouer literêre tekste in die oeuvre van T.T. Cloete
}

Leona Venter

Departement Afrikaans

Universiteit van Pretoria

PRETORIA

\begin{abstract}
Fragments linger in our ears: the re-activation of older literary texts in the oeuvre of T.T. Cloete

Robert Scholes defines the vocation of the lecturer of literature as a commitment "to help our students unlock textual powers", stressing the relation of the text to other texts. Scholes and N.P. van Wyk Louw use different metaphors for the concept of the entwinement of literary texts. I identify (using Louw's metaphor) possible deviations implied by the text(s) of T.T. Cloete: reflection regarding the poet and the origin of the poem; the poet/Cloete functioning as "just another collection of (inter)-texts", by virtue of his erudition and inclusive procédé; an implied personal and extended, international canon; the critical approach to the Afrikaans literature and the focus on the role of the reader via a Medieval text. My aim is to stress the efficacy of the poetry of Cloete to form a comprehensive curriculum.
\end{abstract}

\section{Inleiding}

Robert Scholes (1985:19) maak in sy studie Textual Power (oor "Literary Theory and the Teaching of English") die opmerking: "few poets read theory for advice on the production of poems, but a substantial portion of the audience for theory is composed of teachers". Op die vraag oor wat die dosent/ onderwyser probeer oordra en waarom, is die antwoord volgens Scholes (1985:20): "The object of such study ought to be textuality: textual knowledge and textual skills". Scholes (1985:154) gaan (in weerlegging van Stanley Fish se teorie in Is There a Text in This Class?) van die standpunt uit dat die teks dáár is; dat die (gedrukte) teks ' $n$ transaksie is tussen wat op die blad staan en 
die besondere linguistiese kode wat oorspronklik dit wat daar staan ("those marks") in staat gestel het om betekenis te hê; dat die leser se keuse(s) in die toekenning van betekenis beperk is (ek verkies gerig word) deur die skrywer se keuse "of what marks to put on the page". Die teks(krag) moet deur die leser ontsluit word. Scholes (1985:20) sien dit as die taak van die onderwyser "to help our students unlock textual powers and turn it to their own uses". Wel bewus van Charles Altieri (1990: Inleiding) se kritiek op Scholes se genoemde studie, klink die algemene ideaal vir my na 'n bruikbare omvattende doelstelling. Scholes (1985:20) glo: "We must help them to see that every poem, play, and story is a text related to others, both verbal pre-texts and social sub-texts, and all manners of post-texts including their own responses, whether in speech, writing, or action". Die dosent maak die letterkundestudent volgens hom bewus van ' $n$ weefsel.

Met die gebruik van 'n ander metafoor het N.P. van Wyk Louw (1975b:106) in 1945 al opgemerk: "(Daar gaan) uit elke onderdeel en uit die gehele werk van 'n groot digter tallose sypaaie af; of liewer: dit lyk soos die binneste kring van 'n eindelose reeks wyer kringe met elkeen waarvan dit intiem verbonde is".

Scholes sou waarskynlik in T.T. Cloete se digterlike oeuvre 'n ideaalvoorbeeld kon vind om die verweefdheid waarvan hy praat te demonstreer - Louw om sommige van die "tallose sypaaie" aan te dui. Ek wil (as lid van die bo geïdentifiseerde "audience for theory") in dié studie enkele voorbeelde van Cloete se bruikbaarheid in die klaskamer in die verband aanstip: enkele van die deur die teks geimpliseerde sypaaie as (teks)verkenningsroetes volg. My uitgangspunt is dat die teks as kommunikatiewe strategie aangebied word en dat met die rol van die leser/student tydens die generasie van die teks rekening gehou is (Eco, 1983:3).

\section{Besinning oor die digterskap}

Cloete se poësie dien as funksionele vertrekpunt vir 'n gesprek oor en rondom die digterskap. "Rotsode", die sesde gedig van die eerste afdeling van Jukstaposisie (1982:16), lei 'n besinning rondom die kuns- en kunstenaarsteorie in die bundel in. Die subtitel is "D.J. Opperman". Die gedig verskuif die soeklig intrigerend van die digter in die algemeen na Opperman (onder meer deur die subtitel) en na Cloete (deur herkenbare Potchefstroomse bakens soos "die Heilige Akker" - kerkgrond wat in 'n woonarea omskep is - en "Mohadien", 'n Indiërwoonbuurt). Die gedig fokus onder meer op 'n/die digter se geografiese, sosiale en literêre beïnvloeding en die ontstaanswyse van die poësie. "Rotsode" kan effektief saamgelees word met Cloete se opstel "J.H. Leopold oor die dromende denke" in Kaneel (1970). Cloete (1970:173) verwys 
in dié opstel onder meer na die Nederlandse digter Leopold wat ruimte laat daarvoor dat beelde in die gedig opkom, in die digter opwoel, die digter inneem. Cloete (1970:174) verwys ook na Nijhoff wat praat van toewaaisels van buite of van binne. Die eerste strofe van "Rotsode" inkorporeer van dié ontstaansteorieë:

Onderdanig gereed sit

hy by sy tafel verplig

hoe weet hy deur wie om oor dit

wat hom voorgesê word te dig(.)

Dié onsekerheid het ook spore van onder meer Keats se "Sleep and poetry" (Garrod (ed.), 1939:53):

And many a verse from so strange influence

That we must ever wonder how, and whence

It came.

Cloete (1992b:334) maak onder die lemma "Nasionale literatuur" die volgende uitsprake wat in "Rotsode" neerslag vind: "Ons kan dit nie betwis nie dat die skrywer en sy werk vanselfsprekend gevorm word deur die milieu of konteks (geografies, maatskaplik, godsdienstig, polities, ens.) waarbinne hy leef"; dat literêre werke ook gevorm word "deur literêre werke sélf wat in ánder tale en lande geskryf is (...)". Die hele gedig "Rotsode" is 'n weefsel van beinvloedingsmoontlikhede soos afluister ("na die voorbeeld van Dante", dus ook van die inferno na die paradiso) en 'n "gewone dorp" se gevarieerde vormende bydrae. Die digter word getipeer as "'n tweehelftegesig", 'n Janus, die hoorder van "voorwoordsels" (met naklanke van Nijhoff se "aanwaaisels"), 'n afluisteraar, 'n dief, 'n "verleë/ afhanklike". Die gedig besin (en motiveer die leser/student om te besin) oor invloedstudie ("the connections between literature and society or tradition") sowel as inspirasieteorieë ("the connections between literature and psychology or the individual artist's development" (Morgan, 1985:4)).

Dié soort literêr-teoretiese besinning oor die "how, and whence" word voortgesit in gedigte soos "voëls met nuwe teks" - oor die aanbring/verbyvoer/ voorlees/aandra van "teks"; "Artefaktereëel" (wat mimese afwys) en "ongeluksvoël", wat die digter se "eie stem" (idiolek) wyer as bloot die "keel/ en eie stem" van die voël stel. Al drie die gedigte kom uit Idiolek $(1986: 11,16,17)$. "Die gedig is 'n refleks" en "God die digter" in Driepas $(1989: 34,49)$ bring die leser verder onder die indruk van die selfrefleksiwiteit van die poësie en die voortgesette diskoers rondom die digter(skap). "Die gedig is 'n refleks" konkludeer (na talle vergelykings): 


\section{die gedig van vreugde of pyn ontplof uit donsklein geringhede en word tot 'n wye stelsel uitgestort van gloeiende asteroiede stof(.)}

Twee opvolgbare sypaaie sou kon wees: a) die verkenning van "uitsprake" oor die gedig/digterskap in ander oeuvres (soos dié van Breytenbach en Opperman) of b) 'n verantwoording oor aspekte van Cloete se eie digterlike procédé. Ek volg in laasgenoemde verband net een aspek op: Cloete se inklusiewe werkswyse as produk van en gerigtheid op 'n uitgebreide leeservaring.

\section{3. "just another collection of (inter-)texts"}

Allotroop (1985:139) se laaste bladsy lees: "met dit gedicht vervalt het vorige niet". Dit formuleer uitdruklik 'n leesstrategie wat Joan Hambidge (1990:7) ook in ' $n$ resensie van Driepas benadruk, naamlik: "die gedigte moet nie as afsonderlike verse gelees word nie - die verse speel op mekaar in, is intertekstueel op mekaar aangewys". Dat vorige gedigte nie "verval" nie poneer ook 'n literatuurbeskouing wat spontaan lei tot die volgende verkennende sypad: 'n vergelyking met vroeëre literatuurbeskouings (in hulle historiese konteks). Dit steek die koevoet in onder die opvatting van outonomiebewegings soos die stilistiek op linguistiese grondslag in Nederland en Suid-Afrika in die vyftigerjare, deur Elize Lindes (1956:2) uitgedruk as 'n beskouing dat die gedig "voor die leser op 'n bladsy" staan, "gegroepeer in strofes, met 'n titel wat dit benoem en dit isoleer van soortgelyke betitelde gedigte daarvoor en daarna".

Van al Cloete se bundeltitels bly Jukstaposisie vir my die kensketsendste van sy eie werkwyse, met die implikasie van "naasmekaarplasing", maar ook "toeneming van anorganische lichamen door uitwendige aanzetting, uitwendige aangroei" (De Tollenare \& Persijn, 1984:424) - in oordragtelike sin opgeneem as aansetting, (aan)groei van die gedig, die bundel, die oeuvre, die leeservaring deur die besondere absorpsievermoë en inklusiwiteit van Cloete se poësie. Dit sluit ook - soos reeds geblyk het - die inkorporering van literêrteoretiese besinning in. Cloete doen regdeur sy digterlike oeuvre en besonder gekonsentreerd in die eerste afdeling van Jukstaposisie (1982) wat Hein Viljoen (1992:198) via Fried by Manet uitwys: hy tree direk in 'n "intertekstuele" gesprek met sy voorgangers en open 'n ryk resonansiesfeer vir sy werk. Algaande is daar 'n opvallende aanwas, "toeneming" van eksplisiet aangeduide en implisiet meesprekende tekste. Van die digterlike werkswyse, maar ook van die leser se assosiatiewe betrokkenheid, is die woorde uit "Stories" in Jukstaposisie (p. 24) tiperend: 


\section{(...) Fragmente sloer \\ in ons ore, draal in ons geheue.}

En: dié ervaring van sloerende, dralende fragmente het (in die konteks van die jeugervaring in dié gedig) 'n verruimende funksie - om "'n planeet in ons gehemelte (te) versit".

Die besondere saamsuigkrag/toeneming/ aansetting van en deur die gedig word uitnemend deur "Stories" gedemonstreer. Die subtitel/motto is: "... vangt de fluitketel te fluiten aan" - woorde uit Marthinus Nijhoff se gedig "Impasse"; tegelyk die titel van die voorafgaande gedig in Jukstaposisie. Die getal 1001, saam met "(S)tories", haal Sjahrazad se verhale by. Dié gedig demonstreer wat Morgan (1985:20) van die/'n skrywer sê: dat hy "just another collection of (inter-)texts" is. Eco (1983:10) sê dat die skrywer tekstueel gemanifesteer word as 'n lierkenbare styl of tekstuele idiolek. Cloete se inklusiewe werkswyse stuur die leser op 'n verkenningstog rondom die kenmerkende van sy styl - te meer as hy sy vierde bundel ldiolek noem.

\section{4. 'n Geïmpliseerde persoonlike kanon}

Die talryke verwysings na en absorpsie van ander literatuur ("sloerende fragmente") bring die leser onder die indruk van Cloete se belesenheid. Cloete se digterlike oeuvre konstrueer by implikasie 'n uitgebreide leeslys. So 'n waarneming sluit aan by die diskoers rondom kanon en kanonvorming (waarmee ek nie leeslys en kanon gelyk wil stel nie). Fokkema (1985/6b:6) omskryf 'n literêre kanon as 'n seleksie van bekende en waardevol geagte tekste wat in die onderwys gebruik word en as referensiekader dien vir die literêre kritiek; as - sekerhik gesien uit die standpunt van die literatuurdosent "een richtsnoer van teksten die in ieder geval gelezen moeten worden" (p. 5). Fokkema (1985/6a:3) gee aandag aan die moontlikheid van "verschillende naast elkaar bestaande canons" en praat ook van die moontlike ondersoek van 'n internasionale kanon. Onder die lemma "Kanons en kanonisering" laat Hein Viljoen (1992:196-199) ruimte vir 'n "eie kanon" van werke wat die leser "ken en waardeer". John Neubauer (1985/6:42) omskryf persoonlike kanons as "de samenstelling van individuele verzamelingen die op persoonlijke smaak, belangstelling en wereldvisie gebaseerd zijn". So 'n persoonlike kanon kan seker in 'n mate uit 'n digter se gedigte gekonstrueer word - al is dit ook net, soos Altieri (1990:50) globaal van (die) kanon sê, "quite vague, more an ideal productive network of possibilities than a specific curriculum". 


\section{1 'n Uitgebreide kanon}

By Cloete val die gesuggereerde persoonlike en die internasionale of uitgebreide kanon by implikasie saam. Dit is allermins die doel om te probeer om 'n volledige leeslys uit Cloete se poësie te konstrueer of oral die wyse van absorpsie van ander gedigte of oeuvres na te gaan. Ek dui net enkele verkenningsmoontlikhede aan, met twee uitsprake in gedagte: Neubauer (1985/6:42) s'n dat elke "introduktie tot de literatuur" noodsaaklikerwys selektief "en dus canonvormend" is en Ohlhoff (1993:65) se propaganda vir navorsing van onder meer "literêr-interne prosesse soos intertekstualiteit in al sy verskeidenheid".

Die Bybel resoneer byvoorbeeld deurlopend en op verskillende wyses in Cloete se poësie, soms - om Angelliera (1980) as voorbeeld te gebruik - herkenbaar deur sitate, soos in "Van mossies en meer" (p. 5); soms betrek by wyse van subtitels, byvoorbeeld "Ps. 128" by "Harba lori fa" (p. 11); soms is daar 'n motto, soos by "Haggiolied" (p. 18) die ongespesifiseerde aanhaling van Hooglied 5:6. In "Prediker 11:7" (Jukstaposisie, p. 96) is die titel tegelyk die Bybelverwysing. Job loop by wyse van spreke van bundel tot bundel.

Cloete (1992b:333) wys daarop dat die literatuurgeskiedenis byna altyd uitgaan van die veronderstelling dat die korpus literatuur wat in ' $n$ bepaalde taal en land geskryf is, 'n organiese geheel vorm, waardeur dit te onderskei is van die literatuur van ander tale en ander lande, sodat ons praat van ' $n$ Afrikaanse, ' $n$ Nederlandse literatuur - "iets soos 'n nasionale literatuur". 'n Nasionaal onderskeidende eienskap sou in 'n mate die taal kon wees waarin dié literatuur geskryf is. Natuurlik is dit maar een norm. Cloete (1992b:337) volg in sy bespreking talle ander nuanses rondom "Nasionale literatuur" op en benadruk: as ons praat van byvoorbeeld ' $n$ Afrikaanse literatuur, moet dit altyd wees met die bewussyn van die relatiewe waarde van so 'n onderskeiding. In die volgende voorbeelde gebruik ek slegs die taal en nasionaliteit as merkers.

Dis opmerklik dat bloot deur betiteling en direkte vermelding verskillende letterkundes - 'n internasionale kanon - betrek kan word: die Franse letterkunde (Baudelaire, deur die titel "Correspondances" in Angelliera (p. 4I); Ronsard, deur die subtitel "Na Pierre Ronsard" in Jukstaposisie (p. 70) en Verlaine, deur die subtitel "Na Paul Verlaine" op dieselfde bladspieël (p. 71) en die titel "Verlaine" in Idiolek (p. 77)); die Duitse letterkunde (Goethe, deur die titel "Ober allen gipfeln" in Allotroop (p. 97)); die Engelse letterkunde (A.H. Clough, deur die motto by Jukstaposisie; Milton, deur die motto by "Transisie" in Allotroop (p. 131)); die Italiaanse letterkunde deur die verwysing na Dante in "Rotsode" (Jukstaposisie (p.16), "toepassings van dante" in Idiolek (p. 4951 ) en in die subafdeling "Klawer" in Driepas (157 e.v.). Cloete sê tydens 'n 
optrede by die Universiteit van Pretoria (26 September 1991): Dante het die Middeleeue saamgevat; die hele idee van jukstaposisie is Dantesk byvoorbeeld deur die feit dat die aard(s)e en die erotiese nie in Dante se Commedia ontbreek nie.

Dis veral die Nederlandse letterkunde wat ruim betrek word. Cloete deurloop deur middel van talle verwysings 'n groot deel van die Nederlandse literatuurgeskiedenis. Minstens twee gedigte betrek die Middelnederlandse letterkunde. Die titel "Egidius" in Jukstaposisie (p. 85) is tegelyk ook 'n moontlike verwysing na die Middelnederlandse "Egidius" (Strydom \& Ohlhoff (reds.), 1976:116), 'n wêreldlike kunslied. Die titel ver-teenwoordig dan 'n bekende, konvensionele betekenis in die konteks van die elegiekonvensie. Cloete se gedig dekonstrueer die gesuggereerde 'modelgedig', waarin die spreker mildverwytend verlange uitdruk na sy gestorwe vriend; waarin die gedagte aan die onvermydelike dood ook vir die agtergeblewene die troos van "vruecht" (vreugde) in die vooruitsig stel. Juis die deurbreking van die verwagtingshorison wat deur die titel "Egidius" gewek word, skep die geleentheid vir 'n "vergelykende literatuurstudie in die kleine, om na te vors watter bydrae die interteks kan maak ter verryking van die verwysende teks" (Venter, 1988:198). Nog 'n absorpsie van 'n Middelnederlandse teks geskied deur die gedig "Tiener toneelliefhebber" (Jukstaposisie, p. 20) wat later bespreek sal word.

Revius (en daarmee die Nederlandse Renaissance) word herhaaldelik in die gesigsvlak gebring. In die gedig "in memoriam lenie" in Allotroop (p. 101) geskied dit by wyse van 'n terloopse sitaat: "alleen die verdrink/ (sê Revius) wat gaan staan/ in die stroom en soek na grond". Nog 'n voorbeeld uit Allotroop (p. 134) betrek Revius se poësie deur die motto by "Ons": "behalven dien't Heer/ belieft te openbaren". Dis woorde uit Revius se religieuse sonnet "Scheppinge" (Strydom \& Ohlhoff (reds.), 1976:208). In Revius se gedig is die wêreld 'n luit wat deur God bespeel word. Dis net uitverkorenes - "dien't de Heer belieft" - wat dié musiek hoor. Cloete se gedig word deur die opskrif van die afdeling waarin dit staan as 'n "transisie" aangebied. Die musiekbeeld ontbreek heeltemal, maar nog is God nie "tot ons oor en oog beperk" nie. Die uitverkorenheid om te sien/ervaar/dink word in die vier gedigte in dié afdeling (pp. 131-134) telkens anders belig met ' $n$ ver-teenwoordiging van Milton (in die motto by "Toeris") en van Vondel (weer deur die motto in "Hy"). In "Kunstenaars" word Sophokles, Job, Dawid, Dante, Michelangelo, Rembrandt en (weer) Milton uitdruklik uitgesonder as toegelatenes om "dieper/ af te luister, dieper te kyk en te sien,/ dieper te tas". 
In Jukstaposisie (p. 104) kan die Nederlandse titel "Hechten hier beneden" ook teruggevoer word na Revius (1930:73) se gedig "Hemelsche wandelinge", waarin die woorde in die ontkenningsvorm voorkom: dat God se kinders die wêreld so moet betree dat "hare sinnen niet en hechten hier beneden". Dit is die ideaal van die sewentiende-eeuse Calvinistiese predikantdigter. Die titel betrek dus by implikasie 'n lewens- en wêreldbeskouing. Maar daar is in Cloete se titel twee duidelike merkers van intertekstualiteit. Cloete verbind by implikasie Revius se lewenskyk en 'n joernalistieke teks in Beeld (20 Februarie 1981) deur die verwysing van die subtitel na Manie van der Schijff. Dit lei na die artikel "Transvaal is mooi, maar nou op sy mooiste!" in die rubriek "Die lewe om ons" (Venter, 1988:223). Die handelingsekwensie in Cloete se gedig (sluip, wieg, soek, fluister, loop, stap, wegbly, vermy, regop staan, swem) in 'n kundig gespesifiseerde natuuromgewing is 'n volgehoue kommentaar op Revius se voorbehoude ten opsigte van die "betreden" van die wêreld. Revius se sewentiende-eeuse gedig "verval" nie, maar word ver-teenwoordig deur verbintenisse met lektuur uit die tagtigerjare van ons eeu: met Cloete se gedig en die koerantartikel uit die pen van 'n bekende plantkundige en Havengapryswenner. Cloete se bemoeienis met Revius is belangrik juis in die konteks van kanonisering. Roswitha Schutte (1988:218) merk op dat Revius nie in sy tyd 'n gewilde digter was nie: "Dit is eers in óns eeu, eintlik betreklik onlangs, dat sy werk as't ware herontdek is en werklik gewaardeer word". Cloete aksentueer "Hemelsche wandelinge" deur die absorpsie in "Hechten hier beneden". N.P. van Wyk Louw (1975a:28 en 29) sê in 1952 van die Reviuskwatryn: "Daar is min kort gedigte van vier reëls wat ek ken, wat so volledig en volmaak is" en noem dit 'n "literêre edelsteentjie". Die gedig word op twee verskillende wyses (intertekstueel en literêrkrities) positief gekanoniseer.

Ek verwys verder net na 'n paar voorbeelde wat die leser motiveer om ruimer te lees. 'n Sitaat uit Herman Gorter se $\mathrm{Mei}$ word as motto by "Fyn vrugbare essensie" (Jukstaposisie, p. 42) gebruik: "Er ligt in elk ding schuilend/ fijne essence van and're dingen". Dit formuleer trouens die/'n essensie van Cloete se idiolek: "alles is aan alles verwant in die hemel, op land,/ onderwater" (Driepas, p. 173). Cloete kies ook in die geval van $M e i$ 'n teks van formaat. W.F. Jonckheere (1988:276) noem Mei die "hoogtepunt van Tagtig se liriek" en die eindpunt daarvan.

In Idiolek (p. 62-64), onder die subafdelingtitel "transkripsie", word Hooft (ook uit die Nederlandse Renaissance), Leopold ('n oorgangsfiguur tussen Tagtig en Negentig) en Nijhoff (uit die geslag van die Eerste Wêreldoorlog, die sogenaamde derde geslag ná Tagtig) titelgewys betrek - maar vanselfsprekend nie net in die titel nie. Hendrik Marsman (wat in 1923 debuteer) en Harry 
Mulisch (die naoorlogse romanskrywer wat sy debuut in 1952 maak) kry onderdak in 'n gedig met die enigmatiese, saamgestelde titel "openbaring marsman leipoldt mulisch" (p. 71) wat uiteraard 'n ondersoek na die samevoeging suggereer. Bloem (p. 78), wat ook titelgewys betrek word, hoort tot die generasie van Tien.

Idiolek dring deur die afdelingtitels "transkripsie", "perifrase" en "die aanwesigheid van die afwesigheid" teksintern by die leser aan om hom oor verskillende wyses van herskrywing te verantwoord. Allotroop, met die reedsgenoemde afdelingstitel "Transisie" (p. 131-134) sluit by dié herskrywingsvariante aan. Gedigte werk ooglopend op verskillende wyses met die tematiek en die styl van die aangeduide skrywers en weerspieël soms hulle idiolek, byvoorbeeld Bloem se oorheersende verlange en onvervuldheid as "'n vlagie woorde wat die verderf 'n vleugie transendeer" (Idiolek, p. 78).

Soms is dit net die taal van 'n titel wat 'n aanwysbare interteks suggereer, soos gesien in "Hechten hier beneden". Dit gebeur ook in "ik ben met $u$ alleen 0 venus" (Driepas, p. 19). Twee verskillend aangebode "hartstogtend(e)" gedigte op dieselfde bladspieël - "ek alleen met jou" en genoemde "ik ben met u alleen o venus" - nooi deur die gesuggereerde verskillende sosiale kodes in die titel al tot 'n vergelykende studie. Die Nederlandse titel reik na 'n ander digter, 'n ander Venus en 'n ander stemming uit: na die Vlaming, Karel van de Woestijne, se "Ik ben met u alleen, o Venus" in die 1920-bundel De modderen man. In dié gedig bly die spreker se hart "bar" en "marrend" en die "harde mond" star (Antonissen (red.), 1984:125). Ook hier kan Van de Woestijne se idiolek (in die konteks van sy historiese ontwikkeling as digter) nagegaan word en die funksie van die jukstaponering van Cloete- /Van de Woestijneperspektiewe op die onderskeie digterskappe open.

Jukstaponering van die lewensbeskoulike val dikwels op. Die motto by "Entelegie" (Met die aarde praat, p. 52) is 'n sitaat uit Bredero (weer 'n Renaissancedigter) se "Geestigh-liedt" (Boshoff \& Dekker, 1927:292). Dit plaas die gedig by implikasie in die religieuse sfeer van sondebesef en skuldbelydenis, want:

\footnotetext{
Wat dat de wereld is, dat weet ick al te wis

(God betert) door't versoecken: want ick heb daer verkeert en meer van haer geleerd als vande beste boecken.
} 
Terwyl Bredero worstel met "een hert seer verwoet/ Van duysent na berouwen" en die sondige wêreld en versoeking vooropstaan, bied Cloete se gedig in 'n ander religieuse sleutel 'n bewonderende inventaris van "eksempele eksempla(a)r(e)" van natuurdinge wat die kultuurskeppinge (musiekinstrumente, kantwerk, die versterker, ensovoorts) voorafgegaan het, ewenaar of oortref. Wat "ons" (die mens) op al die geskapene "voor het" is die bewussyn van 'n "uitsluitende Faktor" - van 'n bewuste vra na die "camera obscura agter ons kamera" (Met die aarde praat, p. 54). Die later teks en die boodskap van die teks kry - in die taal van N.P. van Wyk Louw (1972:93) "eintlik(e) pregnansie" deur die saamlees met Bredero se teks.

Ek het opsetlik in die meeste gevalle na bloemlesings verwys. Bekende en voorgeskrewe bloemlesings is 'n vertrekpunt vir die opspoor van tersaaklike gedigte. Van Gorp e.a. (1991:63) benadruk die bepalende funksie van bloemlesings (en literatuuronderrig) ten opsigte van die literêre kanon.

Uit die voorbeelde is dit duidelik dat die onontbeerlikheid van kennis van die Nederlandse letterkunde teksintern deur Cloete benadruk word en dat hy 'n seleksie maak van tekste wat "in ieder geval gelezen moeten worden" (Fokkema, 1985/6:5).

\subsection{Die Afrikaanse letterkunde}

Dit is opmerklik dat die (maklik) aanwysbare toespelings op ander Afrikaanse letterkundige tekste beperk is. Opperman figureer - soos reeds gesien - onder meer deur die subtitel "D.J. Opperman" by "Rotsode" in Jukstaposisie (p. 1617); C.M. van den Heever, Toon van den Heever, W.E.G. Louw en Jan F.E. Celliers ook deur titels in Jukstaposisie (p. 21, 22) en Leipoldt deur titels in Jukstaposisie (p. 19) en Idiolek (p. 65).

"Canons involve values, both in what they preserve and in the principles of preserving" (Altieri, 1990:33). Die eerste afdeling van Jukstaposisie selekteer 'n aantal ouer digters en gedigte en plaas hulle in 'n geïmpliseerde "literaire hiërarchie" (Dijkstra, 1989:161). Ek verwys hier vir uitvoerige(r) besonderhede na die artikel "Vondste uit de oude doos: Hommage à T.T. Cloete" (Venter, 1993:71-84). Die artikel gee (in die konteks van 'n "literaire hiërarchie") aandag aan die gedigte "Leipoldt 100", "Hommage à CM vd Heever" en "N.a.v. FvdH, WEGL en JFEC". Sowel waardeoordeel as verskillende wyses van die uitdrukking daarvan blyk uit die drie gedigte. In die geval van Leipoldt (aan wie 'n gedig van twintig reëls toegeken word en in Idiolek (p. 65) nog 'n dertienreëlige gedig) is daar affmiteit tot en waardering vir die ouer oeuvre wat verteenwoordig word deur "sloerende fragmente" - 'n "catalogue of (...) connotations" (Riffaterre, 1982:8) - regdeur die gedig. Die 
gedig is eintlik 'n teleskopering van Leipoldt se oeuvre en idiolek. In die geval van C.M. van den Heever word in 'n agtreëlige gedig deur die absorpsie van "wildeganse" en die "mooi Indoena" in die gedig twee van Van den Heever se gedigte uitgesonder: "Die vertrekkende wildeganse" en "Die gevalle Zoeloeindoena" - 'n eerbetoon "al is dit vir min" en nog deur "min/mense (ge)lees". C.M. van den Heever se poësie word met die verledevorm van die tweede strofe aan die gewaardeerde maar tydgebonde verlede gekoppel. In die "N.a.v."gedig word Toon van den Heever ("FvdH") se idealisering van die "oop" Hoëveld vervang met positiewe konnotasies rondom die stad. W.E.G. Louw ("WEGL") se geïdealiseerde boer-tema word bevraagteken deur jukstaponering met die werklikheid: negatiewe "Vrystaatse stoftorings". In die geval van Jan F.E. Celliers ("JFEC") is daar 'n uitgesproke kritiek wat tematiek en taal betref: afkerigheid van sy "opgeskroefde geseur/ en geteem by 'n vroegaandvuurtjie (...)". Ook hier is die één gedig van agtien verse (vir die evaluering van drie digters) 'n moontlike "canonindicator" (Dijkstra, 1989:162).

'n Laaste sypad wat ek veral uit die eerste afdeling van Jukstaposisie wil opvolg, is om aandag te gee aan een voorbeeld van die teksinteme oorweging van die rol van die leser.

\section{Die rol van die leser}

Die kritiese instelling in die groepie gedigte met Afrikaanse digtersname as titel val op. Die plasing van twee gedigte - die een oor C.M. van den Heever en die een oor (gesamentlik) Toon van den Heever, W.E.G. Louw en Jan F.E. Celliers - tussen die gedigte "Tiener toneelliefhebber" en "Impasse" (Jukstaposisie, p. 20, 22) het moontlik 'n skadeloosstellende of in elk geval relativerende funksie.

Ohlhoff (1985:50-51) omskryf resepsie as "die ontvangs, reproduksie, aanpassing, assimilasie of kritiese beoordeling van 'n literêre produk of sy elemente deur 'n leser of lesers". Die resepsie kan verskillend plaasvind: "spontaan, krities, naief, wetenskaplik, e.s.m.". Ohlhoff noem (via Ibsch) ten opsigte van reële lesers vier lesertipes en dus resepsiesituasies: die skrywer van literatuur as leser wie se resepsie van 'n literêre teks tot 'n nuwe literêre teks lei (en wat sekerlik in hierdie bespreking duidelik na vore gekom het - L.V.); die kritikus as leser en produsent van 'n (hoofsaaklik) evaluerende teks óór 'n literêre teks; die literatuurhistorikus as leser en produsent van 'n (hoofsaaklik) beskrywende en verklarende teks óór 'n literêre teks; die nie-professionele leser met verskillende grade van ervaring in die omgang met literêre tekste. 
Cloete plaas (teen dié vlugtige teoretiese agtergrond besien) twee gedigte waarin die nie-professionele leser figureer voor en na die gedigte oor C.M. en Toon van den Heever, W.E.G. Louw en Celliers. "Impasse", die later gedig, dra die titel van 'n sonnet deur Marthinus Nijhoff uit die bundel Nieuwe gedichten (1934). Die "impasse" in Cloete se gedig - 'n parodie op die sonnet van Nijhoff (1963:208) - is die dilemma van die 'leser'-gerigte skrywer. Die beterweterige, nie-professionele ontvanger/leser vereis voorskriftelik 'n strak sonnet: metries, vol leestekens, dom - "net wat moeiteloos/ kan lees", wat streel en "plesierig" maak; net "teer emosies". Die gedig is 'n pendant van "Die kritikus" in Angelliera (p. 57). "Die kritikus" satiriseer die (onbevoegde) kritikus - een van genoemde vier leserstipes - wat homself as maatstaf beskou; wat "wie groter as ek is" aflag "tot formaat".

"Tiener toneelliefhebber" suggereer nog 'n ander lesersituasie. Dis onverwags 'n 'toneel'-gedig in 'n poësie-omgewing: 'n resepsie uit die perspektief van 'n onvolwasse "toneelliefhebber". Dis tegelyk in bundelverband 'n verplasing van die Afrikaanse poësietoneel van die jare dertig en vroeër na "die woelige Mark in Maastricht" op "die prosessiedag". Van name soos "Mariken" (strofe een) en "al die emme" soos "Moenen, Maria, Modikak" en die pleknaam "Goue Boom" (strofe twee) geld Riffaterre (1982:110) se toeligting: "These fragments, physically present and visible at the surface of the poem" word ervaar as "foreign bodies with an independent textual preexistence elsewhere". Dit betrek naamlik die mirakelspel Mariken van Nieumeghen wat Dirk Coigneau (1982:7-8) bestempel as "een der Nederlandse 'klassieken"". Willem Kuiper (1985/6:249) noem dit een van die "middelnederlandse top-tien". Dit het ontstaan aan die einde van die vyftiende, die begin van die sestiende eeu en die dramagebeure is gesitueer tussen 1465 en 1500.

Die spreker in Cloete se gedig word om didaktiese redes deur sy moeder daarheen geneem: "om my te stig". Die leser kan die talle 'oop plekke' in die gedig deur kennis van die dramagegewe aanvul. Scholes (1985:21) onderskei lees, interpreteer en kritiseer as drie verwante vaardighede wat deel uitmaak van "a textual competence". 'n Gevoel van onvolledigheid by die leser aktiveer die interpretatiewe proses. Die beknopte verwysings in die gedig veronderstel 'n aktiewe, kompetente leser wat deur close reading die hermeneutiese leidrade na die Middeleeuse mirakelspel kan opvolg. Die (minstens deur die name) aanwysbare interteks word prosagewys in die (drama)teks getipeer as "(D)ie waerachtige ende een seer wonderlijke historie van Mariken van Nieumeghen die meer dan seven iaren metten duvel woende ende verkeerde" (Jonckheere \& Conradie (reds.), 1992:49). Mariken, "een schone, ionghe lustighe maecht" (Jonckheere \& Conradie (reds.), 1992:53, r. 27) - in Cloete se gedig uit 
jeugdige perspektief "die mooi meisie" - gaan volgens die drama inkopies doen in Nieumeghen, so drie myl van haar en haar oom Ghijsbrecht se woonplek af. Sy word vals beskuldig en weggewys deur haar tante by wie sy wil oornag en gaan sit "mestroestich" (p. 62, prosagegewe) onder 'n doringstruik. Moenen met een oog, "toeghemaect" (getooi) as 'n mens (p. 64, r. 158) en onkonvensioneel verfynd in vergelyking met die Middeleeuse voorstelling van die duiwel - bied aan om haar onder andere die sewe "vry kunste" te leer: retorika, musiek, logika, grammatika, geometrie, wiskunde en alchemie. Hy vra dat sy haar naam - sy is na Maria vernoem - sal verander. Sy heet voortaan Emmeken en behou dus die $M$ (van Maria). Moenen koester kenmerkend van die Middeleeuse voorstelling van die duiwel 'n vrees vir die kruisteken, seëninge en die noem van Maria en Christus se naam.

Die gedig werk besonder selektief met die dramagegewens. In die tweede strofe van die gedig is daar bloot 'n opnoem van name en karakters en veral twee opvallende familiêre ombuigings, wat pas in die tienerwaarnemingsfeer en boonop die volkstaal van die drama suggereer: "Emmie" (die Afrikaanse verkleiningsvorm van Emmeken) en "die Josie/ Moenen" - die josie wat ons ken uit 'n uitdrukkings soos "Iemand die josie (joos) in maak". Die sosiolek ondersteun die gemoedelike, ongeërgde houding van die toeskouer.

Emmeken en Moenen het in Antwerpen in die herberg die "Guldene Boom" (Jonckheere \& Conradie (reds.), 1992:93, prosagegewe) tuisgegaan. Hier maak Emmeken kennis met die (soort) karakters na wie Cloete se gedig verwys: onder meer hoere ("vroukens vanden leven" (Jonckheere \& Conradie (reds.), 1992:86, r. 446). Die drama noem "tuysschers" (dobbelaars), "vechters, onghetijdige puytieren" (onbetaamlike hoereerders),/ "coppelersen" (vroulike koppelaars), "camercatten" (bywywe) "of sulken dieren" - dit is "sulke meisies" (p. 94, r. 564-565). Cloete se variante is "snoeshane/ en hoere, die grootbek courtisane/ van die hertog" - waarskynlik hertog Olof (Adolf) wat sy pa, Arent, gevange gehou het (Jonckheere \& Conradie (reds.), 1992:49, prosagegewe).

Die tweede tot vierde strofes van die gedig toon onmiskenbaar 'n adolessente entoesiasme vir die banaliteite in die Goue Boom. Dit gee 'n deurmekaar indruk van opvoering- en omgewingwaarneming. Daar is ook 'n sameflansing van die verhewene en die profane - 'n relativering wat versterk word deur die gemeenskaplike byvoeglike naamwoord by Boom ("Goue") en God se "goue" troon. "God gekroon op sy goue troon" (strofe 3) sluit aan by die tradisionele voorstelling: "God werd gewoonlik voorgesteld als een grijsaard in een rijk kerkgewaad met tiara of keizerskroon" (Van der Merwe (red.), 1956:21 haal 
J.A. Worp aan). Modikak (nog 'n duiwel) word in die drama net deur Moenen aangeroep. In die gedig word 'n visuele verskyning gesuggereer.

Maskeroen (strofe 5) is in die binne-toneel in die drama, die wa-spel, in gesprek met God en Maria. Hy is "advocaet van Luciferre" (Jonckheere \& Conradie (reds.), 1992:105, r. 728). Hierdie wa-spel bring Emmeken ("die mooi Emmetjie", strofe 5), wat vroeër al tekens van berou begin toon het, tot inkeer. Die boosaardige Moenen voer haar in die lug op en gooi haar neer. As sy bewusteloos lê, herken haar oom haar. Moenen maak sy stert - want hy het inmiddels 'n gedaantewisseling ondergaan - van woede nat (p. 119, r. 923). Die tienerwaarnemer se kommentaar is:

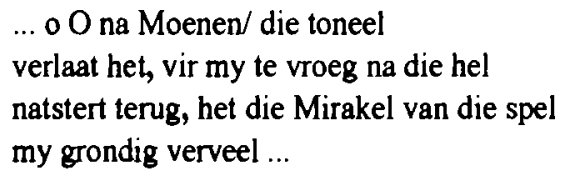

Die 'stig'-telike gaan dus aan die jong kyker - die onvolwasse, onbevoegde kritikus - verby. Wat verder in die drama geskied, is dat Mariken nie in Nieumeghen vryspraak kan kry nie. Sy en haar oom gaan onder meer na "die biskop" (in Colen/ Cuelen; Jonckheere \& Conradie (reds.), 1992:126, prosagegewe). Dan gaan sy na die "Pous" - van wie die tienerwaarnemer slegs die klere noem, in aansluiting by die tradisionele gegewe dat profete, hoëpriesters, heiliges en allegoriese figure in "pragtige gewade uitgedos is" (Van der Merwe (red.), 1956:22). Mariken moet ringe om haar hals en arms dra - tot hulle slyt of self afval. Sy gaan na die klooster in Maestricht (verteenwoordig in die gedig deur die verwysing na "begyne", strofe 3) en leef so heilig dat Christus na meer as vier en twintig jaar 'n engel stuur om die ringe af te haal. Dit is die eintlike "mirakele van onsen lieven Here" (Jonckheere \& Conradie (reds.), 1992:135, prosagegewe). Trouens:

Het happy-end van legenden als Beatrijs, Theophilus én Mariken van Nieumeghen is echter niet het menselijk berouw over zonde zonder meer, maar, typisch middeleeus en katholiek, de miraculeuze bevestiging van de door gebed en boete verkregen genade en vergiffenis (Coigneau (red.), 1982:30).

Die pertinente ouderdomsuggestie in die gedigtitel laat dink aan Scholes (1982:35) se uitspraak: "Some works refuse to open to us until we are sufficiently mature". Ook Eliot (1965:127) sê van byvoorbeeld Shakespeare, Dante, Homer en Vergilius dat die waardering van hulle poësie "a lifetime's task" is, "because at every stage of maturing - and that should be one's whole life - you are able to understand them better". Die onvolwasse toeskouer het 'n 
beperkte "existing stock of experience" (Selden, 1985:112). Die resepsieverslag lewer 'n eie kommentaar op die leser/waamemer, eerder as op die intrinsieke waarde van die waargenomene.

Die keuse van die Middelnederlandse teks aksentueer by herhaling die band tussen die Afrikaanse en Nederlanse tekste en die funksionaliteit van 'n ou teks as draer van ' $n$ nuwe(r) teoretiese benadering.

\section{Slotsom}

Die Cloete-teks (hetsy 'n bundel of sy oeuvre) is in die klaskamer by uitstek 'n bevestiging en demonstrasie van Roland Barthes (1981:137) se opvatting dat die teks nie 'n geslote struktuur is nie, maar 'n "outlet" (Louw se sypadgedagte) na "other texts, other codes, other signs". Hierdie tekstualiteit inkorporeer die ontdekkende rol van 'n gretige leser. Die digte Cloete-teks impliseer opvolgbare sypaaie en lewer deur sy inklusiewe werkswyse en al die "sloerende fragmente" in die woorde van "Elemente" (Jukstaposisie, p. 101) 'n pleidooi dat die leser - die student en die dosent - "wyd/ en onversadigbaar oop" sal wees vir die eie en ander letterkundes.

\section{Bibliografie}

Altieri, C. 1990. Canons and Consequences. Evanston, Illinois : Northwestern University Press.

Antonissen, R. (red.). 1984. Digkuns van die Nederlande. Deel 2. Vyfde druk. Stellenbosch : Universiteit-uitgewers.

Barthes, R. 1981. Textual Analysis of Poe's Valdemar. In: Young, R. (ed.). Untying the Text. Boston : Routledge \& Kegan Paul. p. 133-161.

Boshoff, S.P.E \& Dekker, G. (reds.). 1927. Van Maerlent tot Boutens. Pretoria : Van Schaik.

Cloete, T.T. 1970. Kaneel. Kaapstad : Nasionale Boekhandel.

Cloete, T.T. 1980. Angelliera. Kaapstad : Tafelberg.

Cloete, T.T. 1982. Jukstaposisie. Kaapstad : Tafelberg.

Cloete, T.T. 1985. Allotroop. Kaapstad : Tafelberg.

Cloete, T.T. 1986. Idiolek. Kaapstad : Tafelberg.

Cloete, T.T. 1989. Driepas. Kaapstad : Tafelberg.

Cloete, T.T. 1992a. Met die aarde praat. Kaapstad : Tafelberg.

Cloete, T.T. 1992b. Nasionale literatuur. In: Cloete, T.T. (red.). Literêre terme en teorieë. Pretoria : HAUM-Literêr. p. 333-337.

Coigneau, D. (red.). 1982. Mariken van Nieumeghen. 's-Gravenhage : Nijhoff. 
De Tollenare, F. \& Persijn, A.J. (reds.). 1984. Nieuw Handwoordenboek der Nederlandse Taal. Negende druk. Antwerpen : Van Dale.

Dijkstra, K. 1989. Canonvorming in de literaire communicatie. Spektator, 18(3): 159-168.

Eco, U. 1983. The Role of the Reader. Second edition. London : Hutchinson. Eliot, T.S. 1965. Dante. London : Faber \& Faber.

Fokkema, D.W. 1985/6a. Inleiding. Spektator, 15(1):3-4.

Fokkema, D.W. 1985/6b. De canon als kritisch en didactisch instrument: een historische analyse. Spektator, 15(1):5-15.

Garrod, H.W. (ed.). 1939. The Poetical Works of John Keats. Oxford : Clarendon.

Hambidge, J. 1990. Lywige Driepas sleur mee. Die Transvaler: 7, Febr. 13. Jonckheere, W.F. 1988. Vernuwing van Tagtig. In: Van der Elst, J. (hoofred.). Momente in die Nederlandse letterkunde. Pretoria : Human \& Rousseau-Academica. p. 273-279.

Jonckheere, W.F. \& Conradie, C.J. (reds.). 1992. Mariken van Nieumeghen. Pretoria : HAUM-Literêr.

Kuiper, W. 1985/6. Mariken van Nieumeghen, een gerenoveerd MariaMirakel. Spektator, 15(4):249-267.

Lindes, E. 1956. Veelheid en binding. Amsterdam : Noord-Hollandse uitgevers.

Louw, N.P. van Wyk. 1972. Opstelle oor ons ouer digters. Kaapstad : Human \& Rousseau.

Louw, N.P. van Wyk. 1975a. Swaarte- en ligpunte. Kaapstad : Tafelberg. Louw, N.P. van Wyk. 1975b. 'n Wêreld deur glas. Kaapstad : Tafelberg.

Morgan, T.E. 1985. Is There an Intertext in This Text?: Literary and Interdisciplinary Approaches to Intertextuality. American Journal of Semiotics, 3(4): 1-40.

Neubauer, J. 1985/6. Canonvorming en het thema van de adolescentie in de literatuur. Spektator, 15(1):41-51.

Nijhoff, M. 1963. Verzamelde gedichten. Tweede druk. Den Haag : Bakker. Ohlhoff, H. 1985. Die resepsieteorie. In: Cloete, T.T., Botha E. \& Malan, C. Gids by die literatuurstudie. Pretoria: HAUM-Literêr. p. 50-55.

Ohlhoff, H. 1993. Kanon en kanonisering. Tydskrif vir Letterkunde, 31(4):58-66, Nov.

Revius, J. 1930. Over-Ysselsche sangen en dichten. Uitgegeven door W.A.P. Smit. Amsterdam : Holland.

Riffaterre, M. 1982. Semiotics of Poetry. Fifth edition. Bloomington : Indiana. 
Scholes, R. 1982. Semiotics and Interpretation. New Haven : Yale University Press.

Scholes, R. 1985. Textual Power. New Haven : Yale University Press.

Schutte, R. 1988. Godsdienstige poësie van die 17e eeu. In: Van der Elst, J. (hoofred.). Momente in die Nederlandse letterkunde. Pretoria : Human \& Rousseau-Academica. p. 216-238.

Selden, R. 1985. A Reader's Guide to Contemporary Literary Theory. Great Britain : Harvester.

Strydom, S. \& Ohlhoff, H. (reds.). 1976. Van Middeleeue tot Goue Eeu. Pretoria : Van Schaik.

Van der Merwe, H.J.J.M. (red.). 1956. Mariken van Nieumeghen. Pretoria : Van Schaik.

Van Gorp, H. e.a. (reds.). 1991. Lexicon van literaire termen. Vierde volledig herziene druk. Groningen : Wolters-Noordhof.

Venter, I.L. 1988. Intergedigtelike verhoudings in die poësie van T.T. Cloete, met Jukstaposisie as vertrekpunt. Pretoria : UP. (D. Litt-proefskrif.)

Venter, I.L. 1993. Vondste uit de oude doos: Hommage à T.T. Cloete. Literator, 14(3):71-84, Nov.

Viljoen, H. 1992. Kanons en kanonisering. In: Cloete, T.T. (red.). Literêre terme en teorieë. Pretoria : HAUM. p. 196-199. 
